\title{
Editorial Vol. 73 (3) September 2020
}

\section{B. N. Chakraborty ${ }^{1,2}$}

C Indian Phytopathological Society 2020
The third issue, Volume 73 of Indian Phytopathology for July-September 2020 is ready. In this issue there are twenty four articles including three review articles, fourteen research articles, six short communications, one new report and one Book review.

The first review is presidential address of Dr. M. P. Thakur on the Technological advancement in cultivation of edible mushrooms and promotion of mushroom processed products as potential source of food, nutrition, medicine and employment generation in India. The second review article is B. B. Mundkur Memorial Award Lecture entitled "Nematode infestation, a potential threat to Indian Forests" wherein Dr. Mujeebur Rahman Khan has discussed in depth the significance of nematode which pose a serious threat to forest plants. The third review article by Dr. R. Viswanathan has emphasized on the scenario of wilt and Pokkah boeng diseases of sugarcane and their impact on production and management.

Use of Trichoderma sp. for protection of lentil plants against soil and seed borne pathogens and its bioformulations in combination with fungicide has proved to be effective for growth improvement and management of tomato wilt. Nanoemulsion of mustard oil was evaluated against post harvest anthracnose pathogens. Endophyte mediated defense strategies in banana has been discussed. Microtomy was optimized in screening for disease tolerance cultivars of chickpea. Prevalence of high pathogenic variability among isolates of Stemphylium vesicarium, aggressiveness of Fusarium species on head blight of wheat and influence of weather factors on aerial blight of soybean have been explored. Fumotoxin biosynthetic gene (FUMI) was detected in Fusarium species, while 16Sr II-D phytoplasma group has been identified both in sesame phyllody and in a weed grass. Root-knot nematode infection in Beta vulgaris has been described and its infection in Pisum sativum along with Pseudomonas syringae pv. pisi could be reduced with Rhizobium leguminosarum. Antifungal activity of Bacillus siamensis against Macrophomina phaseolina has been demonstrated. Application of resistance inducers for suppressing the "Witches broom" severity of Citrus aurantifolia in southern Iran and its mixed infection with begomovirus associated with leaf curling of Zinnia elegans in India have been documented. Morphological variability induced by MYMV in mungbean and association of tomato leaf curl New Delhi virus with mosaic and leaf curl disease of Chrysanthemum, incidence of pepper mottle virus infecting chilli and beet curly top Iran virus infecting eggplant and pepper have been described. First report of Lasidiplodia theobromae rot in ripe jack fruit in Sri Lanka has been discussed.

Authors, reviewers, previous as well as newly elected editorial board members, the executive of Indian Phytopathological Society and business manager who have put in lot of efforts to bring out this publication on time are gratefully acknowledged. Authors are requested to submit the best research/review articles to Indian Phytopathology to maintain its quality and high standards.

Prof. B. N. Chakraborty. Chief Editor, Indian Phytopathology.

Publisher's Note Springer Nature remains neutral with regard to jurisdictional claims in published maps and institutional affiliations.
B. N. Chakraborty

bncnbu@gmail.com

Indian Phytopathological Society, New Delhi, India

2 Department of Biological Sciences, Aliah University, Kolkata, India 